\title{
Pengaruh Pemberian Asam Humat pada Media Tanam terhadap Pertumbuhan dan Kandungan Polifenol Daun Binahong (Anredera cordifolia)
}

\author{
Riyandi, Elly Proklamasiningsih, Rochmatino \\ Fakultas Biologi, Universitas Jenderal Soedirman \\ Jalan dr. Suparno 63 Purwokerto 53122 \\ Email: Riyandi.sr@gmail.com
}

Rekam Jejak Artikel:

Diterima : 26/08/2019

Disetujui : 31/01/2020

\begin{abstract}
Binahong (Anredera cordifolia) is one of medicinal plants that is useful as an antioxidant. The main active compounds in Binahong leaves is flavonoids, which are one of the polyphenol compounds. The type of flavonoids contained in Binahong leaves is flavonol. The use of humic acid can improve the quality of planting media so that plant's growth can increase. The purpose of this study was to determine the effect of humic acid on the growth and polyphenol contents in Binahong leaves and determine the effective concentration of humic acid to increase the growth and polyphenol contents in Binahong leaves. This research was conducted at the Greenhouse and Laboratory of Plant Physiology, Faculty of Biology, Jenderal Soedirman University. The method used in this study is an experimental method using a Completely Randomized Design (CRD) consisting of four treatments of humic acid on sand media with a concentration of 0 g. kg-1 $; 4$ g. kg-1; 8 g. kg-1 $; 12$ g. $\mathrm{kg}^{-1}$ and repeated three times. The parameters observed in this study were plant growth including the number of leaves, wet weight and dry weight of plants, and the content of polyphenols in Binahong leaves. The data obtained were analyzed for variety or Analysis of Variance (ANOVA) with a test level of $1 \%$, then continued with Least Significance Different (LSD) with a test level of 5\%. The results showed that the addition of humic acid in the growing media was able to increase growth and the polyphenol contents in Binahong leaves with a concentration of $12 \mathrm{~g}^{\mathrm{kg}} \mathrm{kg}^{-1}$.
\end{abstract}

Keywords: Binahong, Flavonoids, Growth, Humic acid, Polyphenols,

\begin{abstract}
Abstrak
Tanaman Binahong (Anredera cordifolia) merupakan salah satu tanaman obat yang bermanfaat sebagai antioksidan. Kandungan senyawa aktif utama pada daun Binahong yaitu flavonoid yang merupakan salah satu senyawa golongan polifenol. Jenis flavonoid yang terkandung pada daun Binahong adalah flavonol. Penggunaan asam humat dapat meningkatkan kualitas media tanam sehingga pertumbuhan tanaman dapat meningkat. Tujuan dari penelitian ini adalah untuk mengetahui pengaruh asam humat terhadap pertumbuhan dan kandungan polifenol daun Binahong dan menentukan konsentrasi asam humat yang efektif untuk meningkatkan pertumbuhan dan kandungan polifenol daun Binahong. Penelitian ini dilakukan di Greenhouse dan Laboratorium Fisiologi Tumbuhan Fakultas Biologi Universitas Jenderal Soedirman. Metode yang digunakan pada penelitian ini adalah metode eksperimental dengan menggunakan Rancangan Acak Lengkap (RAL) yang terdiri dari empat perlakuan asam humat pada media pasir dengan konsentrasi $0 \mathrm{~g} . \mathrm{kg}^{-1} ; 4 \mathrm{~g} . \mathrm{kg}^{-1} ; 8 \mathrm{~g} . \mathrm{kg}^{-1} ; 12 \mathrm{~g} . \mathrm{kg}^{-1}$ dan diulang sebanyak tiga kali. Parameter yang diamati pada penelitian ini adalah pertumbuhan tanaman meliputi jumlah daun, berat basah dan berat kering tanaman, serta kandungan polifenol pada daun Binahong. Data yang diperoleh dianalisis ragam atau Analysis of variance (ANOVA) dengan taraf uji 1\%, kemudian dilanjutkan dengan uji Beda Nyata Terkecil (BNT) dengan taraf uji 5\%. Hasil penelitian menunjukkan bahwa pemberian asam humat pada media tanam mampu meningkatkan pertumbuhan dan kandungan polifenol daun Binahong dengan konsentrasi 12 g. $\mathrm{kg}^{-1}$.

Kata kunci : asam humat, Binahong, flavonoid, pertumbuhan, polifenol
\end{abstract}

\section{PENDAHULUAN}

Tanaman Binahong merupakan salah satu tanaman obat yang berpotensi untuk dikembangkan karena hampir semua bagian dari tanaman Binahong seperti umbi, batang dan daun dapat digunakan dalam terapi herbal. Tanaman Binahong cepat tumbuh di daerah lembab sehingga sangat berpotensi untuk dikembangkan pada daerah iklim tropis seperti di Indonesia (Hasiib et al., 2015). Bagian tanaman yang paling sering digunakan atau dimanfaatkan untuk kesehatan adalah bagian daun. Berdasarkan hasil penelitian, senyawa metabolit sekunder yang terdapat dalam daun Binahong adalah flavonoid, alkaloid, terpenoid, saponin, dan asam oleanolik (Arifin et al., 2014). Menurut Selawa et al. (2013) daun Binahong diketahui bermanfaat sebagai antioksidan karena mengandung senyawa polifenol yaitu flavonoid. Jenis flavonoid yang diperoleh dari hasil isolasi dan identifikasi 
serbuk segar dan serbuk kering ekstrak etanol daun Binahong adalah flavonol.

Antioksidan diperlukan untuk mencegah stres oksidatif. Stres oksidatif adalah kondisi ketidakseimbangan antara jumlah radikal bebas yang ada dengan jumlah antioksidan di dalam tubuh. Radikal bebas merupakan senyawa yang mengandung satu atau lebih elektron tidak berpasangan dalam orbitalnya, sehingga bersifat sangat reaktif dan mampu mengoksidasi molekul di sekitarnya (lipid, protein, DNA, dan karbohidrat). Antioksidan bersifat sangat mudah dioksidasi, sehingga radikal bebas akan mengoksidasi antioksidan dan melindungi molekul lain dalam sel dari kerusakan akibat oksidasi oleh radikal bebas atau oksigen reaktif antara lain radikal hidroksil $\left(\mathrm{OH}^{-}\right)$, dan anion superoksida $\left(\mathrm{O}_{2}^{-}\right)$(Werdhasari, 2014). Flavonoid merupakan senyawa yang memiliki potensi sebagai antioksidan karena memiliki gugus hidroksil yang terikat pada karbon cincin aromatik sehingga dapat menangkap radikal bebas yang dihasilkan dari reaksi peroksidasi lipid (Dewi et al., 2014). Selawa et al. (2013), menyatakan bahwa senyawa yang mampu menecegah dan menghilangkan efek radikal bebas adalah antioksidan. Antioksidan menstabilkan radikal bebas dengan melengkapi kekurangan elektron yang ada pada radikal bebas, dan menghambat terjadinya reaksi berantai peroksidasi lipid.

Senyawa polifenol ditandai dengan adanya cincin aromatik yang membawa lebih dari satu ion. Polifenol dapat dibagi lebih lanjut menjadi dua golongan: flavonoid (flavon, flavonol, flavanon, flavanol, isoflavon, antosianidin dan kalkon) dan tanin (polimer asam fenolat, katekin atau isokatekin) (Luthria, 2006). Senyawa-senyawa tersebut merupakan hasil metabolit sekunder dari tanaman yang berkontribusi dalam warna dan sifat organoleptik lainnya pada tanaman. Senyawa golongan polifenol seperti flavonoid dapat digunakan untuk mengobati antidiabetes antiarthritis, antivirus, antijamur, antioksidan, dan penyakit kardiovaskular (Keerthi et al., 2014).

Senyawa-senyawa kimia pada media tanam yang mempunyai peranan penting bagi pertumbuhan adalah bahan organik. Media tanam memerlukan bahan organik dalam proses pertumbuhan tanaman. Salah satu bahan organik pada media tanam adalah asam humat. Asam humat adalah zat organik yang terdapat di dalam tanah dan gambut. Asam humat merupakan bahan makromolekul polielektrolit yang memiliki gugus fungsional seperti $-\mathrm{COOH},-\mathrm{OH}$ fenolat maupun - $\mathrm{OH}$ alkoholat, sehingga asam humat memiliki peluang untuk berikatan dengan ion logam karena gugus ini dapat mengalami pelepasan proton pada $\mathrm{pH}$ yang relatif tinggi (Setyowati \& Ulfin, 2007). Asam humat adalah komponen terpenting dari senyawa humus karena dari hasil penelitian diketahui bahwa, asam humat membantu menggemburkan tanah, membantu transfer nutrien dari tanah kedalam tanaman, serta meningkatkan retensi kandungan air, dan membantu pertumbuhan mikroba di dalam tanah (Suwahyono, 2011). Penelitian yang dilakukan oleh (Chen et al., 2001), bahwa dengan penambahan asam humat ke tanah termasuk tanah pasir dapat menstimulasi pertumbuhan yang lebih baik daripada hanya

Penelitian ini memiliki tujuan untuk mengetahui pengaruh asam humat terhadap pertumbuhan dan kandungan polifenol daun Binahong dan menentukan konsentrasi asam humat yang efektif untuk meningkatkan pertumbuhan dan kandungan polifenol daun Binahong. Hasil penelitian ini diharapkan dapat memberikan informasi ilmiah kandungan polifenol daun Binahong serta memberikan informasi ilmiah tentang pemakaian asam humat sebagai induktor peningkatan kandungan polifenol daun Binahong.

\section{MATERI DAN METODE}

Bahan-bahan yang digunakan dalam penelitian ini adalah tanaman Binahong (Anredera cordifolia), asam humat, media pasir, dan reagen Folin Ciocalteu. Alat yang digunakan dalam penelitian ini adalah Vacum Rotary Evaporator dan spektrofotometer UV-Vis.

Penelitian ini dilaksanakan di Greenhouse dan Laboratorium Fisiologi Tumbuhan Fakultas Biologi Universitas Jenderal Soedirman Purwokerto yaitu pada bulan Maret hingga Juni 2018. Metode penelitian yang digunakan adalah metode eksperimental dengan menggunakan Rancangan Acak Lengkap (RAL) dengan 4 perlakuan. Perlakuan yang digunakan adalah pemberian 4 konsentrasi asam humat yaitu 0 g. $\mathrm{kg}^{-1} ; 4 \mathrm{~g}$. $\mathrm{kg}^{-1} ; 8$ g. $\mathrm{kg}^{-1}$; dan $12 \mathrm{~g}$. kg-1 Parameter utama yang diamati pada penelitian ini adalah pertumbuhan dan kandungan polifenol pada daun Binahong. Parameter pertumbuhannya yaitu jumlah daun, berat basah tanaman dan berat kering tanaman.

\section{Pembuatan Media Tanam}

Media tanam dibuat dengan mencampurkan pasir dengan asam humat sesuai perlakuan, dan penambahan pupuk AB-Mix yang telah dilarutkan dengan aquades. Penyiraman pupuk AB-Mix sesuai dengan nilai kapasitas lapang.

\section{Penanaman Bibit dan Perawatan Binahong}

Bibit ditanam ke dalam polybag yang sudah berisi media. Keseragaman bibit yang diambil dilihat dari bentuk dan ukuran umbi Binahong. Perawatan meliputi penyiraman, pengendalian gulma, hama dan penyakit sesuai dengan kondisi lingkungan.

\section{Pengamatan}

Pengamatan dilakukan pada akhir penelitian (10 MST), meliputi: 


\section{a. Pertumbuhan Tanaman}

Pengamatan dilakukan pada akhir penelitian (10 MST) yaitu :

1. Jumlah Daun

Jumlah daun tanaman dihitung dengan cara menghitung jumlah daun total pada tanaman.

2. Bobot Basah Tanaman (gram)

Seluruh bagian tanaman yaitu akar, batang dan daun ditimbang menggunakan timbangan analitik.

3. Bobot Kering Tanaman (gram)

Seluruh bagian tanaman yaitu daun, batang, dan akar dikeringkan dalam oven dengan suhu $70{ }^{\circ} \mathrm{C}$, kemudian didinginkan dengan suhu ruang dan ditimbang hingga memperoleh berat dengan nilai yang konstan.

\section{b. Pengukuran Larutan Standar}

Pengukuran larutan standar dilakukan menggunakan asam galat dengan metode Folin Ciocalteu. Larutan standar diinkubasi pada suhu ruang selama 1,5 jam dan diukur absorbansinya dengan spektrofotometer dengan panjang gelombang $760 \mathrm{~nm}$.

\section{c. Pengukuran Kandungan Polifenol}

Pengambilan data dilakukan pada akhir penelitian (10 MST). Ekstrak kentaldaun Binahong hasil maserasi dengan pelarut etanol diukur kadar polifenolnya dengan menggunakan metode Folin Ciocalteu. Sampel ekstrak kental sebanyak $50 \mathrm{mg}$ dilarutkan dengan $250 \mu 1$ reagen Folin Ciocalteu ditunggu hingga 1 menit, ditambahkan $750 \mu \mathrm{l} \mathrm{Na}$ karbonat 20\%, dan ditambahkan akuades hingga volume $10 \mathrm{ml}$. Larutan sampel diinkubasi pada suhu ruang selama 1,5 jam. kemudian, larutan sampel diukur absorbansinya dengan spektofotometer dengan panjang gelombang $760 \mathrm{~nm}$.

Data yang diperoleh dianalisis dengan analisis ragam atau Analysis of Variance (ANOVA) kemudian dilanjutkan dengan $\mathrm{Uji}$ Beda Nyata Terkecil (BNT) dengan taraf uji $5 \%$.

\section{HASIL DAN PEMBAHASAN}

Hasil analisis ragam menunjukkan bahwa penambahan asam humat berpengaruh sangat nyata terhadap pertumbuhan tanaman. Berdasarkan uji BNT menunjukkan bahwa penambahan asam humat pada media tanam mampu meningkatkan pertumbuhan tanaman Binahong (Tabel 1). Perlakuan pemberian asam humat yang paling efektif untuk meningkatkan pertumbuhan tanaman adalah perlakuan $\mathrm{AH}_{3}\left(12 \mathrm{~g} . \mathrm{kg}^{-1}\right)$. Hal tersebut dapat terjadi karena asam humat pada konsentrasi tersebut mempunyai nilai kapastitas tukar kation (KTK) yang optimum sehingga kemampuan tanaman pada penyerapan unsur hara oleh akar menjadi optimum. Penambahan asam humat ke media tanam dapat meningkatkan KTK karena asam humat mengandung gugus $-\mathrm{COOH}$ (karboksil) dan $-\mathrm{OH}$ (fenolik). Menurut Tan (1993) semakin tinggi konsentrasi asam humat maka sumbangan gugus fungsional dari karboksil (-COOH) dan fenolik ($\mathrm{OH})$ semakin besar, yang berarti pula muatan negatif media tanam semakin meningkat. Peningkatan muatan negatif ini terukur sebagai peningkatan KTK tanah. Suwahyono (2011) menyatakan bahwa asam humat dapat berperan merekondisikan tanah sebagai medium tanam menjadi lebih baik. Asam humat dapat mengikat air di dalam tanah, kemampuan tukar ion yang tinggi, meningkatkan kesuburan tanah dan pertumbuhan tanaman.

Asam humat dapat meningkatkan pertumbuhan tanaman Binahong karena KTK yang tinggi juga karena kandungan unsur hara yang terdapat pada asam humat. Unsur hara yang terdapat pada asam humat antara lain adalah karbon, hidrogen, oksigen, serta sejumlah kecil nitrogen dan sulfur. Menurut Tan (1993) kadar nitrogen dalam asam humat berkisar antara $2-5 \%$ sehingga dapat meningkatkan nilai N-total. Selain N-total dan C-organik yang meningkat, pemberian asam humat juga meningkatkan P- tersedia dalam tanah. Hal ini dikuatkan dengan pernyataan Hermanto et al. (2013) bahwa fraksi humat dapat menyediakan unsur hara seperti $\mathrm{N}, \mathrm{P}, \mathrm{K}$, dan $\mathrm{S}$ ke dalam tanah serta $\mathrm{C}$ sebagai sumber energi bagi mikrobia tanah, sehingga proses metabolisme primer tanaman baik.

Tabel 1. Uji BNT Pengaruh Pemberian Asam Humat pada Media Tanam terhadap Pertumbuhan (Jumlah Daun, Berat Basah, dan Berat Kering)

\begin{tabular}{cccc}
\hline Perlakuan & $\begin{array}{c}\text { Jumlah } \\
\text { Daun }\end{array}$ & $\begin{array}{c}\text { Berat } \\
\text { Kering }(\mathrm{g})\end{array}$ & $\begin{array}{c}\text { Berat } \\
\text { Basah }(\mathrm{g})\end{array}$ \\
\hline $\mathrm{AH}_{0}($ Kontrol $)$ & $47,3^{\mathbf{c}}$ & $5,273^{\mathbf{c}}$ & $47,647^{\mathbf{c}}$ \\
$\mathrm{AH}_{1}\left(4{\left.\mathrm{~g} \cdot \mathrm{kg}^{-1}\right)}^{-1}\right.$ & $58,0^{\mathbf{b}}$ & $6,277^{\mathbf{c}}$ & $57,200^{\mathbf{c}}$ \\
$\mathrm{AH}_{2}\left(8 \mathrm{~g} \cdot \mathrm{kg}^{-1}\right)$ & $64,7^{\mathbf{b}}$ & $7,790^{\mathbf{b}}$ & $77,527^{\mathbf{b}}$ \\
$\mathrm{AH}_{3}\left(12{\left.\mathrm{~g} \cdot \mathrm{kg}^{-1}\right)}^{\mathbf{a}}\right.$ & $86,3^{\mathbf{a}}$ & $10,277^{\mathbf{a}}$ & $101,770^{\mathbf{a}}$ \\
\hline
\end{tabular}

Keterangan: Angka yang diikuti huruf yang sama tidak berbeda nyata pada uji BNT $5 \%$.

Hasil penelitian menunjukkan bahwa asam humat mampu meningkatkan jumlah daun Binahong, berat basah tanaman, dan berat kering tanaman semakin meningkat dengan meningkatnya konsentrasi asam humat yang ditambahkan pada media tanam. Hal tersebut dapat terjadi karena asam humat pada konsentrasi tersebut memiliki kemampuan penyerepan unsur hara yang tinggi sehingga unsur hara yang diperlukan tanaman dalam pertumbuhan menjadi tersedia. Meningkatnya jumlah daun Binahong sejalan dengan hasil penelitian Darwati dan Rosita (1998) yang menyatakan bahwa pemberian asam humat dapat meningkatkan jumlah daun pada stek brotowali. Menurut Gardner et al. (1991) perkembangan daun dalam jumlah yang mencukupi dapat mendukung 
proses fotosintesis. Menurut Restida et al. (2014) asam humat berperan baik dalam proses pertumbuhan dan produksi tanaman dengan cara meningkatkan laju fotosintesis. Unsur hara yang terdapat pada asam humat dapat meningkatkan kadar protein dalam tanaman dan berperan dalam pembentukan klorofil. Kandungan klorofil yang banyak dalam daun dapat meningkatkan laju fotosintesis, sehingga mengakibatkan pertumbuhan dan produksi tanaman menjadi optimal. Pertumbuhan tanaman yang optimal inilah yang berakibat pada peningkatan jumlah daun, tinggi tanaman, berat basah dan berat kering tanaman.

Hasil analisis ragam menunjukkan bahwa penambahan asam humat berpengaruh sangat nyata terhadap kandungan polifenol daun Binahong. Berdasarkan uji BNT menunjukkan bahwa penambahan asam humat pada media tanam mampu meningkatkan kandungan polifenol daun Binahong (Tabel 2).

Tabel 2. Uji BNT Pengaruh Pemberian Asam Humat pada Media Tanam terhadap Kandungan Polifenol

\begin{tabular}{cc}
\hline Perlakuan & $\begin{array}{c}\text { Kandungan Polifenol } \\
(\mathrm{ppm})\end{array}$ \\
\hline $\mathrm{AH}_{0}($ Kontrol $)$ & $48,167^{\mathbf{d}}$ \\
$\mathrm{AH}_{1}\left(4 \mathrm{~g}^{\mathrm{kg}} \mathrm{kg}^{-1}\right)$ & $69,797^{\mathrm{c}}$ \\
$\mathrm{AH}_{2}\left(8 \mathrm{~g} \cdot \mathrm{kg}^{-1}\right)$ & $92,513^{\mathbf{b}}$ \\
$\mathrm{AH}_{3}\left(12{\left.\mathrm{~g} . \mathrm{kg}^{-1}\right)}^{\mathrm{a}}\right)$ & $106,910^{\text {a }}$ \\
\hline
\end{tabular}

Keterangan: Angka yang diikuti huruf yang sama tidak berbeda nyata pada uji BNT 5\%

Berdasarkan Tabel 2, perlakuan pemberian asam humat yang paling efektif untuk meningkatkan kandungan polifenol pada daun Binahong adalah perlakuan $\mathrm{AH}_{3}$. Hal tersebut dapat terjadi karena pada konsentrasi tersebut pertumbuhan tanaman Binahong optimum sehingga hasil metabolit primer menjadi optimum. Metabolit sekunder merupakan senyawa turunan dari metabolit primer yang merupakan prekursor sintesis metabolit sekunder, sehingga meningkatnya metabolit primer dapat meningkatkan metabolit sekunder seperti polifenol (flavonoid). Menurut Saifudin (2014) metabolit sekunder berasal dari metabolit primer. Starting material dari biosintesis metabolit sekunder salah satunya berasal dari hasil metabolit primer yaitu glukosa.

Biosintesis metabolit sekunder dibagi menjadi dua jalur. Jalur pertama adalah metabolisme dasar seperti glikolisis dan siklus Krebs, dan jalur kedua adalah jalur sikimat. Jalur sikimat merupakan jalur yang paling umum pada biosintesis senyawa polifenol. Menurut Anttonen dan Karjalainen (2008) jalur senyawa polifenol yang paling umum yaitu jalur asam sikimat yang bermula dari kondensasi antara phosphoenolpyruvate (PEP) dan erythose 4-phospate dari jalur pentophosphat membentuk asam amino aromatik fenilalanin dan tirosin. Fenilalanin merupakan substrat untuk enzim phenylalanine ammonia-lyase (PAL), yang berfungsi untuk mengkatalisis reaksi pertama pada jalur fenilpropanoid yang mengarah pada pembentukan sebagian besar senyawa polifenol.

Beberapa unsur hara yang dapat mempengaruhi produksi metabolit sekunder adalah $\mathrm{Cu}, \mathrm{Mg}$, dan $\mathrm{S}$. Unsur $\mathrm{Cu}$ dapat meningkatkan aktivitas enzim PAL sehingga mampu meningkatkan produksi senyawa polifenol terhadap tanaman ginseng asia (Panax ginseng) (Ali et al., 2006). Unsur Mg dapat membentuk senyawa sianidin yang merupakan salah satu aglikon antosianin. Unsur $\mathrm{S}$ dalam senyawa $\mathrm{SO}_{4}{ }^{2-}$ merupakan elemen penting dalam sintesis protein dan produksi senyawa metabolit sekunder dalam tanaman seperti flavonoid (Tripatmasari, 2008).

\section{SIMPULAN}

Pemberian asam humat mampu meningkatkan pertumbuhan tanaman dan kandungan polifenol daun Binahong. Konsentrasi asam humat sebesar 12 g. $\mathrm{kg}^{-1}$ efektif meningkatkan pertumbuhan tanaman dan kandungan polifenol daun Binahong.

\section{DAFTAR REFERENSI}

Ali, M.B., Singh, N., Shohael, A. M., Hanh E. J., \& Paek K.Y. 2006. Phenolics Metabolism and Lignin Synthesis in Root Suspension Cultures of Panax gingseng In Response to Copper Stress. Plant Sciences, 171(1), pp.147-154.

Anttonen, M. J. \& Karjalainen, R. O. 2008. Evaluation of Means to Increase the Content of Bioactive Phenolic Compounds in Soft Fruits. I International Symposium on Biotechnology of Fruit Species: Biotechfruit, p. 839.

Arifin, H., Wijaya, R. J. \& Rizal, Z. 2014. Pengaruh Ekstrak Etanol Daun Binahong (Anredera cordifolia (Ten.) Steenis Terhadap $\mathrm{pH}$ dan Tukak Lambung pada Tikus Putih Betina. Jurnal Farmasi Higea, 6(1), pp. 28-45.

Chen, Y., Clapp, C. E. \& Magen, H. 2001. Plant Growth Stimulation by Humic Substances and Their Complexes with iron. Proceedings International Ferilizer Society Symposium

Darwati, I. \& Rosita, S. M. D. 1998. Penggunaan Asam Humat Untuk Meningkatkan Pertumbuhan Setek Brotowali. Warta Tumbuhan Obat Indonesia, 4(2), pp. 7-8.

Dewi, N. W. O. A. C., Puspawati, N. M., Swantara, I. M. D., Asih. I. A.R.A., \& Rita, W. S. 2014. Aktivitas Antioksidan Senyawa Flavonoid Ekstrak Etanol Biji Terong Belanda (Solanum betaceum, syn) dalam Menghambat reaksi 
Peroksidasi Lemak pada Plasma Darah Tikus Wistar. Cakra Kimia, 2(1), pp. 7-16.

Gardner, F. P., Pearce, B. \& Mitchell, R. L. 1991. Physiology of Crop Plants (Fisiologi Tanaman Budidaya, Terjemahan Herawati Susilo). Jakarta: UI Press.

Hasiib, E.A., Riyanti \& Hartono, M. 2015. Pengaruh Pemberian Ekstrak Daun Binahong (Anredera cordiifolia (Ten.) Steenis) dalam Air Minum Terhadap Performa Broiler. Jurnal Ilmiah Peternakan Terpadu, 3(1), pp. 14-22.

Hermanto, D., Dharmayani, N. K. T., Kurnianingsih, R. \& Kamali, S. R. 2013. Pengaruh Asam Humat sebagai Pelengkap Pupuk Terhadap Ketersediaan dan Pengambilan Nutrien pada Tanaman Jagung di Lahan Kering Kecamatan Bayan-NTB. Ilmu Pertanian (Agricultural Science), 16(2), pp. 28-41.

Keerthi, M., Prasanna, J. L., Aruna, M. S. \& Rao, N. R. 2014. Review of Polyphenol as Nature Gifts. World Journal of Pharmacy an Pharmaceutical Sciences, 3(4), pp. 445-455.

Luthria, D. L. 2006. Influence of Sample Preparation on the Assay of Phytochemicals. American Laboratory, 38(7) pp. 12-14.

Restida, M., Sarno \& Ginting, Y. C. 2014. Pengaruh Pemberian Asam Humat (Berasal dari Batubara Muda) dan Pupuk $N$ terhadap
Pertumbuhan dan Produksi Tanaman Tomat (Lycopersicum esculentum Mill). Jurnal Agrotek Tropika, 2(3), pp. 482-486.

Saifudin, A. 2014. Senyawa Alam Metabolit Sekunder: Teori, Konsep, dan Teknik Pemurnian. Yogyakarta: Deepublish.

Selawa, W., Runtuwane, M. R. J. \& Citraningtyas, G. 2013. Kandungan Flavonoid dan Kapasitas Antioksidan Total Ekstrak Daun Binahong (Anredera cordifolia (Ten.) Steenis). Pharmacon, 2(1), pp. 18-22

Setyowati, D. \& Ulfin, I. 2007. Optimasi Kondisi Penyerapan Ion Aluminium Oleh Asam Humat. Akta Kimia Indonesia Journal, 2(2), pp. 85-92

Suwahyono, U. 2011. Prospek Teknologi Remediasi Lahan Kritis dengan Asam Humat (Humat Acid). Jurnal Teknologi Lingkungan, 12(1), pp. 55-65

Tan, K. H. 1993. Principles of Soil Chemistry. New York: CRC Press

Tripatmasari, M. 2008. Pengaruh Pemupukan dan Terhadap Produksi Antosianin Daun dan Kuersetin Umbi Tanaman Daun Dewa (Gynura pseudochina (L) Dc). Tesis. Sekolah Pascasarjana, Institut Pertanian Bogor.

Werdhasari, A. 2014. Peran Antioksidan Bagi Kesehatan. Jurnal Biotek Medisiana Indonesia, 3(2), pp. 59-68. 